\title{
THE EFFECT OF SODIUM HYDROXIDE SPRAY TREATMENTS OF MAIZE COBS ON CONSUMPTION AND DIGESTIBILITY BY THE WEST AFRICAN DWARF SHEEP
}

\author{
By \\ I.O.A. ADELEYE \\ Department of Animal Science, University of Ibadan, Ibadan, Nigeria.
}

\section{SUMMARY}

A Sodium Hydroxide spray treatment of ground maize cobs was evaluated in a feeding trial with West African Dwarf rams. $\mathrm{NaOH}$ solution of $6 \%$ concentration was sprayed on ground maize cobs at the rate of 50 litres per $100 \mathrm{~kg}$, representing a $3 \% \mathrm{NaOH}$ treatment level. The treated maize cobs were airdried before being incorporated into the experimental diets. The apparent digestibility coefficients for dry matter (DM), crude protein (CP), crude fibre (CF) and gross energy (GE) were significantly higher in the diet containing $\mathrm{NaOH}$ - treated maize cobs (diet B) than the diet containing the untreated maize cobs (diet A). Addition of sucrose (purified cane sugar) at $3 \%$ level to the $\mathrm{NaOH}$-treated malze cobs (diet C) produced a slight increase in voluntary feed consumption but did not have any significant effect on nutrient digestibility when compared with diet $\mathbf{B}$. Relative intake (RI), nutritive value index (NVI) and digestible energy (DE) intake values were significantly higher in diets B and C. Average daily weight gains were also significantly higher in the diets containing $\mathrm{NaOH}$-treated maize cobs (diets $\mathrm{B}$ and $\mathrm{C}$ ), while the efficiency of feed utilization values were closely related to the daily weight gains.

\section{INTRODUCTION}

Grass straw, grain husks; maize cobs, sugarcane bagasse, sawdust etc. are examples of low - quality roughages. Their low digestibility and voluntary intake when fed to animals are mainly due to their high content of lignin, which acts as an encrusting material for the plant cell nutrients (Cramption and Maynard, 1938). By treating them with delignifying agents digestibility and voluntary intake can be increased. This was first demonstrated many years ago by
Beckmann (1921), While the Beckmann process has proved useful in small-scale farm operations, wide-scale use has been limited owing to the large volume of dilute $\mathrm{NaOH}$ solutions required, the tedious washing operations to remove excess alkali and the losses of soluble nutrients during the washing operation. The "dry" process of alkali treatment reported by Wilson and Pigden (1964) has eliminated the need for washing as excess alkali was neutralised with acetic acid; while the recent spray method (Singh and Jackson, 1971) has completely removed the necessity for washing and neutralization with acid. The objective of this study was to evaluate the effectiveness of the $\mathrm{NaOH}$ spray treatment in increasing voluntary feed intake and digestibility of maize cobs when fed to West African Dwarf sheep.

\section{MATERIALS AND METHODS}

The maize cobs used in this experiment were obtained from the University of Ibadan Teaching and Research Farm. The maize cobs were sun-dried and then ground in a hammer-mill through a $3 \mathrm{~mm}$ sieve. A 3\% level of $\mathrm{NaOH}$ treatment was used, which in practice was achieved by mixing $97 \mathrm{~kg}$ of ground maize cobs with $3 \mathrm{~kg}$ of $\mathrm{NaOH}$ pellets. The reason for using a $3 \% \mathrm{NaOH}$ was to eliminate the necessity for washing or neutralizing the excess sodium hydroxide after treatment. 


\section{NaOH - SPRAYED MAIZE COBS IN SHEEP NUTRITURE}

It is possible that increasing the amount of residual alkali may have an adverse effect on rumen fermentation, and may also lead to high intake of sodium which can interfere with the acid-base equilibrium of the animals being fed the treated material. The $3 \mathrm{~kg} \mathrm{NaOH}$ pellets were dissolved in 50 litres of solution $(6 \% \mathrm{~W} / \mathrm{V})$. Treatment of the maize cobs with the $\mathrm{NaOH}$ solution was done in a concrete vat having a capacity of approximately $3.6 \mathrm{cu}$ metres. Thorough mixing was effected by spraying the $\mathrm{NaOH}$ solution on the maize cobs from a watering - can and turning the mixture with garden shovels. Some heat was evolved during the mixing and the colour of the maize cobs changed from grey to golden yellow. It must however be empahsized that the handling and spraying of sodium hydroxide are hazardous operations which must be undertaken with caution. If by any chance it comes in contact with the body, dilute glacial acetic acid is preferred to water in washing the affected part of the body. The treated maize cob was put in clean drums, covered and left for $24 \mathrm{hr}$. so as to allow adequate reaction of the $\mathrm{NaOH}$ with the lignin. After this, the material was air-dried for two days. Samples of untreated and $\mathrm{NaOH}$ - treated maize cobs were analyzed for their proximate composition.

\section{Animal studies}

Twelve ram lambs of the West African Dwarf sheep, 8-10 months of age and weighing between 12.3 and $21.4 \mathrm{~kg}$ were selected from the sheep flock and used for the feeding trial. The animals were randomly divided into 3 groups of 4 animals each. A group was assigned to one of the experimental diets shown in Table 2 . Prior to the experiment, the animals were managed on a semi-intensive system of husbandry. They were grazed from 08.00 to $12.00 \mathrm{hr}$. on Giant Star grass (Cynodon nlemfuensis) and scattered stands of Centrosema pubescens. Afterwards, they were group-fed some concentrate supplement ration made up maize/guinea corn, groundnut cake and palm kernel meal at approximately $0.25 \mathrm{~kg}$ per head daily.

During the experimental period, the animals were put in individual feeding pens and fed the appropriate diet ad libitum once daily $(09.00 \mathrm{hr}$.) in order to allow for maximum voluntary feed intake determinations. Fresh water was available in plastic buckets and each animal was provided with a block of trace-mineralized salt lick. The animals were weighed weekly for the first six weeks, while the seventh week was used for the digestibility studies.

Faecal collection and chemical analyses

Faecal collection was done by means of

TABLE 1

Proximate composition of treated and untreated ground maize cobs (Dry basis)

\begin{tabular}{lcc}
\hline Criteria & $\begin{array}{c}\text { Untreated } \\
\text { maize cobs }\end{array}$ & $\begin{array}{c}\text { NaOH-treated } \\
\text { maize cobs }\end{array}$ \\
\hline Crude protein $(\%)$ & 2.8 & 2.6 \\
Crude fibre $(\%)$ & 36.5 & 34.4 \\
Ether extract $(\%)$ & 1.4 & 1.1 \\
Ash $(\%)$ & 6.5 & 11.7 \\
Nitrgen-free extract $(\%)$ & 52.8 & 50.2 \\
Gross energy $(\mathrm{KJ} / \mathrm{g})^{*}$ & 18.0 & 16.7 \\
\hline
\end{tabular}




\section{ADELEYE}

\section{TABLE 2}

Composition of experimental diets +

\begin{tabular}{lccc}
\hline \multicolumn{1}{c}{ Ingredients (\%) } & \multicolumn{3}{c}{ Experimental diets } \\
\hline Untreated maize cobs & $\mathrm{A}$ & $\mathrm{B}$ & $\mathrm{C}$ \\
NaOH-treated maize cobs & 50.0 & - & - \\
Sucrose (purified cane sugar) & - & 50.0 & 47.0 \\
Yellow maize & - & - & 3.0 \\
Dried Brewers grains & 26.0 & 26.0 & 26.0 \\
Groundnut cake & 17.0 & 17.0 & 17.0 \\
Vitamin A \& D crumbles & 6.0 & 6.0 & 6.0 \\
\hline \multicolumn{1}{c}{ Total } & 1.0 & 1.0 & 1.0 \\
\hline
\end{tabular}

+ Trace mineralized salt-lick blocks were available to all animals

TABLE 3

Proximate composition and energy value of experimental diets (dry matter basis)

\begin{tabular}{|c|c|c|c|}
\hline \multicolumn{4}{|c|}{ Experimental Diets } \\
\hline Criteria & A & B & C \\
\hline Crude protein (\%) & 11.14 & 11.05 & 10.97 \\
\hline Crude fibre (\%) & 22.25 & 19.43 & 18.67 \\
\hline Bther extract (\%) & 3.31 & 3.21 & 3.23 \\
\hline Ash (\%) & 4.29 & 6.95 & 6.47 \\
\hline Nitrogen-free extract (\%) & 59.01 & 59.36 & 60.66 \\
\hline Gross energy (KJ/g) & 18.91 & 17.61 & 17.86 \\
\hline
\end{tabular}

collection bags fitted to harnesses. The total wet faeces excreted daily were weighed and aliquot sample (about $10 \%$ ) was taken and dried in a forced-draught oven at $80^{\circ} \mathrm{C}$ for $24 \mathrm{hr}$. The dried faecal samples for each animal over the 7-day collection period were bulked and sampled. The samples were milled and stored in tight-fitting glass bottles until required for chemical analysis. Proximate composition of the feed and faecal samples were carried out using the A.O.A.C. (1970) methods.

\section{Sumbtical analyses.}

The data were analyzed using the analyzis of variance procedure (Steel and
Torrie, 1960). Statistical significance between treatment means was determined by the Duncan's multiple range test (1955).

\section{RESULT AND DISCUSSION}

The data presented in Table 1 show the effect of $\mathrm{NaOH}$ treatment on the chemical components of ground maize cobs. The alkali treatment resulted in slight reduction of all the chemical components except the ash content which showed a considerable increase when compared with the untreated cobs. The increased ash content as a result of $\mathrm{NaOH}$ treatment was directly responsible for the observed lower gross energy values of the treated 


\section{NaOH - SPRAYED MAIZE COBS IN SHEEP NUTRITURE}

samples, since ash has no energy value. The observed reduction in the other chemical components (crude protein, crude fibre, eiter extract and nitrogenfree extract) could be due to the diluting effect of $\mathrm{NaOH}$.

The chemical composition data of the experimental diets are presented in Table 3. It could be noted that the major effect of incorporating $\mathrm{NaOH}$-treated maize cobs into diet B was an increase in the ash content and a decrease in the gross energy value when compared with $\operatorname{diet} \mathbf{A}$ in which the untreated maize cobs were used. Also to be noted was the fact that addition of purified cane sugar (sucrose) at $3 \%$ level to the $\mathrm{NaOH}$-treated maize cob (diet C) did not have any effect on the gross energy content of the diet indicating that the gross energy of sucrose and cellulose (maize cobs) are about equal.

Data on feed intakes and apparent nutrient digestibilities are presented in
Table 4. A highly significant $(\mathrm{P}<0.01)$ increase in dry matter and gross energy digestibility coefficients was observed in diets $\mathrm{B}$ and $\mathrm{C}$ in which $\mathrm{NaOH}$-treated maize cobs were used. It could be noted that the coefficients of gross energy digestibility were similar to those of dry matter. This similarity could be explained by the fact that the dry matter fraction of any diet, excluding the ash, is predominantly a source of energy. The digestion coefficients for crude protein and crude fibre were also significantly $(\mathrm{P}<0.05)$ higher in diets $\mathrm{B}$ and $\mathrm{C}$ than in $\operatorname{diet} \mathrm{A}$, while the digestion coefficients for either extract and nitrogen-free extract did not show any significant differences. The results showed a marked improvement in the digestibility of nutrients as a result of alkali treatment of the maize cobs. However, the addition of sucrose (diet C) did not have any significant effect on nutrient digestibility (when compared

TABLE 4

Apparent nutrient digestibility coefficients and feed intakes

Experimental Diets

S.E.

Parameters

Digestion coefficients:

Dry matter (\%)

Crude protein $(\%)$

Crude fibre (\%)

Ether extract $(\%)$

N.F.E. $(\%)$

Gross energy (\%)

Relative Intake (RI)

Nutritive Value Index (NVI)

Digestible Energy (DE) Intake $56.9^{\mathrm{a}}$

$59.5^{\mathrm{a}}$

$48.1^{\mathrm{a}}$

63.4

68.9

$53.2^{\mathrm{a}}$

$57.1^{\mathrm{a}}$

$30.4^{\mathrm{a}}$

$109.9^{a}$
B

$65.1^{\mathrm{b}}$

$66.3^{\mathrm{b}}$

$56.7^{\mathrm{b}}$

62.9

72.1

$61.8^{b}$

$70.6^{\mathrm{b}}$

$43.6^{\mathrm{b}}$

$146.8^{b}$ of means

C

$67.4^{\mathrm{b}}$

$64.7^{b}$

$2.77^{* 0}$

$2.14^{\circ}$

3.21 *

1.04 (NS)

0.98 (NS)

$2.35 * *$

$3.79 * *$

$1.64^{*}$

$3.11^{*}$

** Highly significant treatment differences $(\mathrm{P}<0.01)$

* Significant treatment differences $(\mathrm{P}<0.05)$

(NS) No significant treatment differences $(P<0.05)$

$\mathrm{a}, \mathrm{b}$ : Values on the same line having different superscript letters differ significantly $(\mathrm{P}<0.05)$. 


\section{ADELEYE}

with diet B), although there was a trend in this direction in the case of crude fibre digestibility. This observation is in agreement with the suggestion by Kane, Jacobson and Damewood (1959) that crude fibre digestion by rumen micro-organisms is enhanced by the addition of soluble carbohydrate at fairly low levels.

The voluntary feed intake values were expressed relative to the voluntary consumption of good quality hay (Cramption, Donefer and Lloyd, 1960). Diet A had a significantly $(\mathrm{P}<0.01)$ lower relative intake $(R I)$ value than diets $B$ and C. A number of reports, including Donefer, Adeleye and Jones (1969), have shown a depression in relative intake of alkali-treated forages owing to reduced palatability. This situation appears to hold when the alkali-treated roughages alone constitute the entire diet. But when used as a portion of the diet as in this study, palatability probably plays a minor role in influencing the animal's voluntary feed consumption. Also, the observed significant increases in nutrient digestibility would further increase the voluntary consumption of the diets containing the $\mathrm{NaOH}$-treated maize cobs (Balch and Campling, 1962; Baumgardt, 1970) The fact that addition of sucrose at $3 \%$ level did not result in any significant increases in relative intake values was a clear indication that a source of readily available energy was not a factor limiting the voluntary consumption of the diets containing the $\mathrm{NaOH}$-treated maize cobs. Beames (1960) similarly showed that molasses (unpurified cane sugar) did not produce any significant response in feed intake and body weight gains when fed as a supplement to poor quality hay in cattle feeding trials.

The nutritive value index (NVI) and the digestible energy (DE) intake values were calculated from the RI values and the coefficient of energy digestibility (Cramption, Donefer and Lloyd, 1962). Diet A had significantly $(\mathrm{P}<0.05)$ lower NVI and $\mathrm{DE}$ intake values than diets $\mathrm{B}$ and $\mathrm{C}$. It could also be noted that the trend and magnitude of the differences observed in the NVI and DE intake values are similar to those of RI from which they were calculated.

The data on liveweight changes and efficiency of feed utilization are presented in Table 5. The animals fed untreated maize cob diet (A) had significantly $(P<0.05)$ lower average daily weight

\section{TABLE 5}

Live weight changes and efficiency of feed utilization

\section{Experimental Diets}

S.E. of

\begin{tabular}{lrrrr}
\hline \multicolumn{1}{c}{ Parameters } & \multicolumn{1}{c}{ A } & B & C & $\begin{array}{c}\text { S.E. of } \\
\text { means }\end{array}$ \\
\hline Average daily feed intake (g) & $442.8^{\mathrm{a}}$ & $593.2^{\mathrm{b}}$ & $621.4^{\mathrm{b}}$ & $14.42^{* *}$ \\
Initial live weight $(\mathrm{kg})$ & 17.1 & 17.2 & 17.2 & - \\
Final live weight $(\mathrm{kg})$ & $20.7^{\mathrm{a}}$ & $23.1^{\mathrm{b}}$ & $23.4^{\mathrm{b}}$ & $0.82^{*}$ \\
Average daily weight gain (g) & $73.7^{\mathrm{a}}$ & $119.6^{\mathrm{b}}$ & $127.2^{\mathrm{b}}$ & $4.36^{*}$ \\
Feed efficiency (gain/feed \%) & $16.6^{\mathrm{a}}$ & $20.2^{\mathrm{b}}$ & $20.5^{\mathrm{b}}$ & $1.18^{*}$ \\
\hline
\end{tabular}

*. Highly significant treatment differences $(\mathrm{P}<0.01)$

- Significant treatment differences $(P<0.05)$

a,b: Values on the same line having different superscript letters differ significantly $(P<0.05)$. 


\section{NAOH - SPRAYED MAIZE COBS IN SHEEP NUTRITURE}

gains than those fed the $\mathrm{NaOH}$-treated maize cob diets ( $\mathrm{B}$ and $\mathrm{C}$ ). The final live weights of the animals were closely related to the daily weight gains. Similarly the efficiency of feed utilization values were significantly $(\mathrm{P}<0 . \mathrm{O} 5)$ lower in $\operatorname{diet} \mathrm{A}$ than diets $\mathrm{B}$ and $\mathrm{C}$.

The results of this study have shown that $\mathrm{NaOH}$ spray treatment of low-quality roughages, such as maize cobs, couid serve as a means of increasing their nutrient digestibility and voluntary consumption, and thus form a substantial portion of a production ration to be fed to ruminant animals.

\section{REFERENCES}

A.O.A.C. 1970. Official Methods of Analysis (11th ed.) Association of Official Analytical Chemists, Washington, D.C.

BALCH, C.C. and CAMPLing, R.C, 1962. Regulation of voluntary feed intake in ruminanats. Nutr. Abs. and Rev. 32. 6690

Baumgardi, B.R. 1970. Voluntary feed intake by ruminants; models and practical applications. Proc. Cornell Nutr. Conf. for Feed Manufacturers pg. $85-92$.

BeAmes, R.M. 1960. The supplementation of low quality hay and pasture with molasses and molasses urea mixtures. Proc. Aust. Soc. Anim. Prod. 3. $86-92$.

BECKMANN, E. 1921. Conversion of grain straw and lupins into feeds of high nutrient value. Chem. Abstr. 16: 765.
Crampton, E.W., Donefer, E. and Lloyd, L.E. 1960. A nutritive value index for forages. J. Anim. Sci. 19: 538-544.

Cramption, E.W., Donefer, E. and Lloyd, L.E. 1962. Calorific equivalent of the nutritive value index. J. Anim. Sci. 21: 628-632.

CRAmption, E.W. and MAYnARD, L.A. 1938. The relation of cellulose and lignin content to the nutritive value of animal feeds. J. Nutr. 15: 383-395.

Donefer, E., Adeleye, 1.O.A. and Jones, T.A.O.C. 1969. Effect of urea supplementation on the nutritive value of $\mathrm{NaOH}$-treated oat straw. Advances in Chem. Series 95: 328-342.

DunCAN, D.B. 1955. Multiple Range and Multiple F - tests. Biometrics 11: $1-42$.

Kane, E.A., Jacobson, W.C. and Damęood Jr. P.M. 1959. Effect of corn starch on digestibility of alfalfa hay. J. Dairy Sci. 42: 849 .

SINGH, M. and JACKSON, M.G, 1971. The effect of different levels of sodium hydroxide spray treatment of wheat straw on consumption and digestibility by cattle. J. Agr. Sci. (Camb.) 77: 5 -10 .

STEEl R.G.D: and ToRrie, J.H. 1960. Principles and Procedures of Statistics. McGraw-Hill Book Co. Inc. N.Y.

WILSON, R.K. and PIGDEN, W.J. 1964. Effect of sodium hydroxide treatment on the utilization of wheat straw and poplar wood by rumen microorganisms. Canadian J. Anim. Sci. 44: $122-123$. 